Deleuze's Difference and Repetition 


\section{Edinburgh Philosophical Guides Series}

Titles in the series include:

Kant's Critique of Pure Reason

Douglas Burnham with Harvey Young

Derrida's Of Grammatology

Arthur Bradley

Heidegger's Being and Time

William Large

Plato's Republic

D. J. Sheppard

Spinoza's Ethics

Beth Lord

Descartes' Meditations on First Philosophy

Kurt Brandhorst

Nietzsche's Thus Spoke Zarathustra

Douglas Burnham and Martin Jesinghausen

Deleuze's Difference and Repetition

Henry Somers-Hall

Foucault's History of Sexuality Volume I, The Will to Knowledge Mark Kelly

Kant's Groundwork of the Metaphysics of Morals

John Callanan

Visit the Edinburgh Philosophical Guides Series website at www.euppublishing.com/series/edpg 


\title{
Deleuze's Difference and Repetition
}

\author{
An Edinburgh Philosophical Guide
}

\author{
Henry Somers-Hall
}


(C) Henry Somers-Hall, 2013

Edinburgh University Press Ltd

22 George Square, Edinburgh EH8 9LF

www.euppublishing.com

Typeset in 10.5/13pt Monotype Baskerville by Servis Filmsetting Ltd, Stockport, Cheshire, and printed and bound in Great Britain by CPI Group (UK) Ltd, Croydon CR0 4YY

A CIP record for this book is available from the British Library

ISBN 9780748646784 (hardback)

ISBN 9780748646777 (paperback)

ISBN 9780748669677 (webready PDF)

ISBN 9780748669684 (epub)

ISBN 9780748669691 (Amazon ebook)

The right of Henry Somers-Hall

to be identified as author of this work

has been asserted in accordance with

the Copyright, Designs and Patents Act 1988. 